\title{
ANALISIS DAYA SAING DAN POTENSI EKSPOR MOBIL INDONESIA DI KAWASAN ASIA SELATAN
}

\author{
Abi Revyansah Perwira ${ }^{(1)^{*}}$ \\ ${ }^{(1)}$ Badan Pusat Statistik \\ "email korespondensi: abi.revyansah@bps.go.id
}

\begin{abstract}
Abstrak.
Mobil Indonesia berada di peringkat empat sebagai komoditas non-migas dengan nilai ekspor tertinggi. Oleh karena itu, Kementerian Perindustrian meluncurkan program "Making Indonesia 4.0" pada tahun 2018 dimana salah satu targetnya adalah menjadikan Indonesia sebagai pengekspor mobil terbesar di kawasan Asia Tenggara. Berkaitan dengan hal tersebut, daya saing mobil Indonesia di pasar ekspor layak untuk diselidiki. Penelitian ini menganalisis daya saing mobil Indonesia di kawasan Asia Selatan karena selain belum menerapkan peraturan emisi yang ketat, penjualan mobil di kawasan ini mempunyai tren yang positif. Data penelitian adalah data ekspor mobil Indonesia ke empat negara Asia Selatan yaitu Bangladesh, India, Pakistan, dan Sri Lanka periode 2006 - 2019. Data tersebut dianalisis dengan menggunakan tiga metode: Revealed Symmetric Comparative Advantage (RSCA), Export Product Dynamics (EPD), dan X-Model Potential Export Products. Rata-rata indeks RSCA bernilai negatif yang menunjukkan bahwa daya saing mobil Indonesia masih lemah di keempat negara Asia Selatan, tetapi indeks RSCA bernilai positif hanya di Pakistan sejak 2016. Berdasarkan matriks EPD, mobil Indonesia berada di posisi Rising Star di tiga negara kecuali Sri Lanka yang berada pada posisi Falling Star. Analisis X-Model menunjukkan bahwa Bangladesh, India, dan Pakistan merupakan pasar potensial sebagai tujuan ekspor mobil Indonesia meskipun daya saing masih lemah, hanya Sri Lanka yang kurang potensial.
\end{abstract}

Kata kunci: EPD, Daya Saing, Mobil Indonesia, RSCA.

\begin{abstract}
.
Indonesia automobile is ranked fourth as a non-oil and gas commodity with the highest export value. Therefore, the Ministry of Industry launched the "Making Indonesia 4.0" program in 2018 where one of the targets is to make Indonesia the largest car exporter in the Southeast Asia region. In this regard, the competitiveness of Indonesia automobile in the export market deserves to be investigated. This study analyzes the competitiveness of Indonesia automobile in the Central Asia region because besides the countries in this region do not implement strict emission regulations yet, automobile sales in this region have a positive trend. The observation data are Indonesian automobile export data to four Central Asian countries, namely Bangladesh, India, Pakistan and Sri Lanka for the period 2006 - 2019. The data are analyzed by applying three methods: Revealed Symmetric Comparative Advantage (RSCA), Export Product Dynamics (EPD), and X-Model Potential Export. Products. The average RSCA indices are negative which indicates that the competitiveness of Indonesian automobile is still weak in the four Central Asian countries, but the RSCA indices have positive values only in Pakistan since 2016. Based on the EPD matrix, the Indonesian automobile is in the Rising Star position in three countries except for Sri Lanka which is in the Falling Star position. The X-Model analysis shows that Bangladesh, India, and Pakistan are potential markets as export destinations for Indonesian automobile, although competitiveness is still weak, only Sri Lanka is less potential.
\end{abstract}

Keywords: EPD, Competitiveness, Indonesian Automobile, RSCA.

\section{PENDAHULUAN}

Ketika suatu negara menganut system perekonomian terbuka, ekspor merupakan instrumen penting dalam mendongkrak pertumbuhan Produk Domestik Bruto (PDB) melalui penerimaan devisa. Selain itu, pasar ekspor pada umumnya mempunyai standar 
kualitas baku komoditas ekspor yang mendorong negara-negara pengekspor untuk berusaha mengembangkan komoditas ekspor milik mereka supaya bisa bersaing di pasar internasional.

Sayangnya, sebagai negara dengan jumlah penduduk dan sumber daya alam terbesar di ASEAN, kontribusi ekspor Indonesia terhadap PDB masih rendah dimana Indonesia menempati posisi ke-8 di antara negara-negara ASEAN lainnya (World Bank, 2021). Selain itu, ekspor Indonesia masih didominasi oleh komoditas mentah beserta olahannya dari sektor pertanian (Sari et al., 2014). Oleh karena itu, Indonesia perlu meningkatkan industri manufakturnya yang fokus pada komoditas ekspor dengan nilai-tambah yang tinggi.

Tabel 1. Kontribusi Ekspor Negara-negara ASEAN

\begin{tabular}{lccc}
\multicolumn{4}{c}{ terhadap GDP $(\%)$} \\
\hline \multicolumn{1}{c}{ Negara } & 2017 & 2018 & 2019 \\
\hline Singapura & 170.71 & 177.68 & 173.52 \\
Vietnam & 101.59 & 105.83 & 106.80 \\
Malaysia & 70.01 & 68.57 & 65.22 \\
Kamboja & 60.68 & 61.60 & 61.09 \\
Thailand & 66.68 & 64.87 & 59.77 \\
Brunei Darussalam & 49.57 & 51.93 & 57.95 \\
Filippina & 29.55 & 30.21 & 28.34 \\
Indonesia & 20.18 & 20.97 & 18.41 \\
Myanmar & 28.36 & 30.39 & N/A \\
Laos & N/A & N/A & N/A
\end{tabular}

Sumber: World Bank (2021)

Menurut Kementerian Perdagangan Republik Indonesia, komoditas yang memiliki nilai-tambah tinggi dan potensi ekspor besar adalah otomotif khususnya mobil. Fakta ini didukung oleh Gabungan Industri Kendaraan Bermotor Indonesia) dimana industri mobil Indonesia mengalami pertumbuhan pesat selama 15 tahun terakhir baik penjualan domestik dan ekspor (Gambar 1). Ditambah lagi, Badan Pusat Statistik (BPS) menyebutkan bahwa dalam periode tersebut tenaga kerja yang diserap dalam industri mobil juga meningkat dari 50 ribuan tenaga kerja menjadi 200 ribuan tenaga kerja.
Meskipun demikian, Gambar 1 juga menunjukkan kesenjangan besar antara penjualan domestik dan ekspor. Kesenjangan ini disebabkan oleh permintaan domestik yang besar, proteksi dari negara pengimpor, investasi yang rendah pada industri tersebut, minimnya diferensiasi produk, dan/atau kurangnya koneksi di pasar internasional (Abedini \& Péridy, 2009).

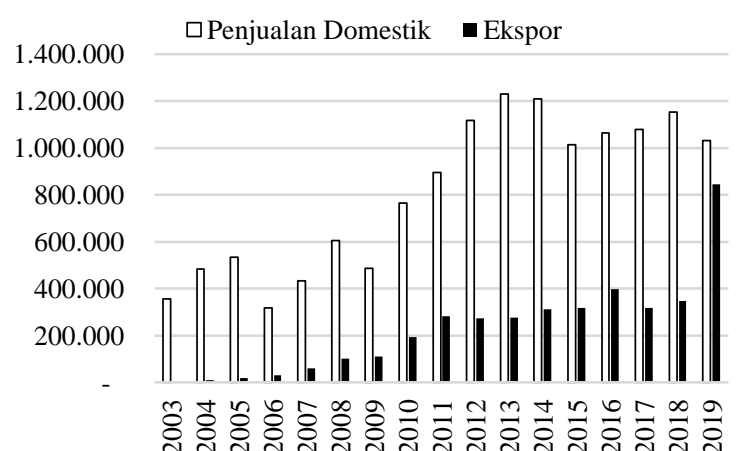

Gambar 1. Penjualan Domestik dan Ekspor Mobil Indonesia (Gaikindo, 2021a)

Kementerian Perindustrian Republik Indonesia meluncurkan program "Making Indonesia 4.0" pada tahun 2018 untuk memperkuat ekspor mobil dimana salah satu target utama jangka panjangnya adalah Indonesia menjadi pemimpin ekspor mobil di kawasan ASEAN. Untuk mendukung program Making Indonesia 4.0 maka daya saing ekspor otomotif Indonesia harus diidentifikasi.

Penelitian sebelumnya tentang daya saing ekspor Indonesia hampir semuanya menganalisis komoditas mentah beserta olahannya dari sektor pertanian (Alexander \& Nadapdap, 2019; Asrol \& Heriyanto, 2017; Ermawati \& Saptia, 2013; Hagi et al., 2012; Hasibuan et al., 2012; Kaunang, 2013; Kusuma \& Firdaus, 2015; Nauly et al., 2014; Nihayah, 2012; Nurhayati et al., 2018; Patone et al., 2020; Pradipta, 2014; Purnamasari et al., 2014; Sarwono \& Pratama, 2014; Satryana \& Karmini, 2016; Syahputra et al., 2014; Tupamahu, 2015; Zuhdi \& Suharno, 2015) dan perikanan (Ashari et al., 2016; La Ola, 2014; Mashari 
et al., 2019; Tumengkol et al., 2015). Selain itu, hanya beberapa penelitian sebelumnya yang fokus pada daya saing ekspor kawasan atau negara-negara tertentu (Ashari et al., 2016; Kusuma \& Firdaus, 2015; Patone et al., 2020; Satryana \& Karmini, 2016; Tupamahu, 2015; Wardani \& Mulatsih, 2017; Zuhdi \& Suharno, 2015), sedangkan pada penelitian lainnya tidak. Oleh karena itu pada penelitian-penelitian yang tidak membahas secara khusus kawasan atau negara-negara tertentu tujuan ekspor tidak ada implikasi kebijakan yang spesifik.

Organization for Economic Cooperation and Development (OECD) merupakan satu-satunya penelitian yang pernah mengobservasi daya saing ekspor otomotif Indonesia bersama dengan empat sektor lainnya. Namun, OECD tidak menganalisis daya saing ekspor otomotif Indonesia secara khusus dan mendalam.

Beberapa perusahaan otomotif di Indonesia telah berencana untuk menambah investasi dan produksinya dalam rangka mengembangkan pasar ekspor mobil Indonesia (Gaikindo, 2021b).

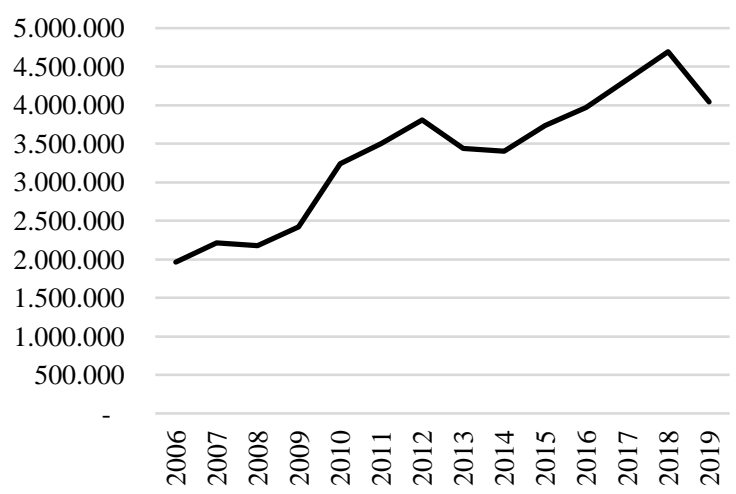

Gambar 2. Penjualan Mobil Baru di Asia Selatan (unit) (OICA, 2021)

Untuk memperjelas ke mana seharusnya Indonesia memperluas ekspor mobilnya maka identifikasi mitra dagang yang potensial sangat penting dalam penelitian daya saing ekspor. Penelitian ini fokus pada kawasan Asia Selatan sebagai salah satu target ekspor Indonesia berdasarkan kajian yang dilakukan oleh Bank Indonesia (Departemen Kebijakan Ekonomi dan Moneter, 2018). Ditambah lagi, negaranegara di kawasan Asia Selatan telah menjadi importir bagi 8.5 persen komoditas ekspor Indonesia (Direktorat Perencanaan Makro dan Analisis Statistik, 2020). Selain itu, tren penjualan mobil baru di Asia Selatan juga cenderung mengalami peningkatan berdasarkan data Organisation Internationale des Constructeurs d'Automobiles (OICA) (Gambar 2).

Berkaitan dengan latar belakang tersebut, penelitian ini mencoba mengkaji daya saing ekspor mobil Indonesia di negara-negara kawasan Asia Selatan. Hasil dari kajian tersebut bisa digunakan dalam menentukan langkah-langkah strategis yang bisa dilakukan untuk meningkatkan ekspor mobil di kawasan Asia Selatan.

\section{KAJIAN PUSTAKA}

\section{Perdagangan Internasional}

Perdagangan internasional bisa terjadi ketika suatu negara tidak mempunyai atau tidak mampu memproduksi komoditas yang dimiliki oleh negara lain dan begitu juga sebaliknya., sehingga terjadi kesepakatan bilateral untuk saling memenuhi komoditas yang dibutuhkan oleh masing-masing negara (Salvatore, 2013).

Menurut (Krugman et al., 2018), ada dua hal utama yang mendorong negaranegara untuk berdagang. Pertama adalah masing-masing negara memiliki karakteristik yang unik seperti sumber daya, teknologi, dan pola konsumsi. Kedua, suatu negara harus memproduksi dalam jumlah tertentu supaya tercapai increasing return to scale dimana tidak semua hasil produksi bisa dikonsumsi oleh penduduk dalam negeri dan harus diekspor.

Pasar internasional memberikan dampak positif baik secara eksternal maupun internal. Secara eksternal, pasar internasional menjanjikan pendapatan yang 
tinggi secara berkelanjutan. Sedangkan secara internal, pasar internal berpeluang untuk meningkatkan kapasitas produksi dalam negeri sehingga bisa menyerap tenaga kerja lebih banyak.

\section{Daya Saing}

Dalam perdagangan internasional ada banyak negara mengekspor komoditas yang sama sehingga timbul persaingan di antara negara-negara pengekspor dalam merebut pangsa pasar. Oleh karena itu, negara-negara pengekspor tersebut berusaha untuk meningkatkan daya saing komoditas mereka dengan cara melakukan efisiensi produksi, memperluas jaringan pasar, dan menciptakan varian-varian baru.

Daya saing suatu komoditas bergantung pada dua hal yaitu keunggulan produktivitas dan biaya produksi relatif terhadap negara pesaing lain (Krugman et al., 2018). Daya saing bisa digolongkan menjadi empat kategori: kinerja ekonomi, kinerja pemerintah, efisiensi bisnis, dan infrastruktur (Salvatore, 2013).

\section{Indeks Keunggulan Komparatif}

Daya saing komoditas suatu negara bisa diukur dengan menghitung keunggulan komparatif. Metode perhitungan keunggulan komparatif yang kerap digunakan dalam penelitian sebelumnya adalah Revealed Comparative Advantage (RCA) (Bano \& Scrimgeour, 2012; Ermawati \& Saptia, 2013; Herciu, 2013; Kaunang, 2013; Mushanyuri \& Mzumara, 2013; Sarwono \& Pratama, 2014; Suntharalingam et al., 2011).

Namun, RCA memiliki kelemahan yaitu memiliki nilai indeks asimetris (Gandolfo, 2014; Laursen, 2015). Akibatnya, indeks RCA tidak bisa digunakan begitu saja dalam model ekonometrika (Laursen, 2015). Oleh karena itu, beberapa penelitian sebelumnya menggunakan Revealed Symmetric Comparative Advantage (RSCA) dan membandingkan antara indeks RCA dengan
RSCA (Laursen, 2015; Nihayah, 2012; Rossato et al., 2018; Startienè \& Remeikienè, 2014).

\section{Potensi Ekspor}

Meskipun suatu komoditas memiliki nilai ekspor rendah, belum tentu komoditas tersebut tidak tidak mempunyai daya saing. Suatu komoditas ekspor dikatakan dinamis jika pertumbuhan nilai ekspornya melebihi pertumbuhan rata-rata seluruh komoditas ekspor. Esterhuizen (2006) memperkenalkan metode Export Product Dynamics (EPD) untuk mengidentifikasi apakah suatu komoditas ekspor mempunyai performa dinamis atau tidak.

Pada Gambar 3, sumbu X adalah posisi pangsa pasar suatu komoditas ekspor di negara pengimpor, sedangkan sumbu $\mathrm{Y}$ adalah posisi pangsa pasar semua komoditas ekspor di negara pengimpor. Matriks EPD memanfaatkan daya tarik pasar sebagai sumbu X dan kekuatan bisnis sebagai sumbu Y.

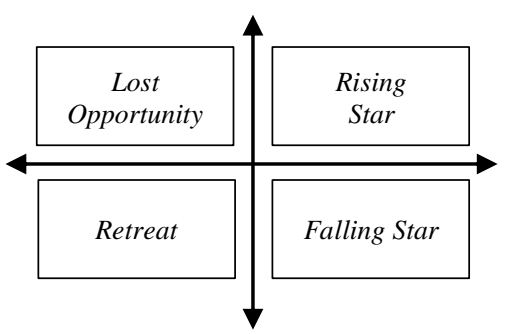

Gambar 3. Matriks EPD

Matriks EPD dibagi menjadi 4 posisi: "Rising Star", "Falling Star", "Lost Opportunity", dan "Retreat" (Gambar 2). Wardani \& Mulatsih (2017)menjelaskan bahwa "Rising star" merupakan posisi paling disukai dimana komoditas ekspor dapat berkembang pesat. "Falling Star" adalah posisi kurang menguntungkan dimana komoditas ekspor turun ketika pangsa pasar ekspor naik. "Lost Opportunity" adalah posisi paling tidak menguntungkan dimana komoditas ekspor dinamis tetapi pangsa pasar negara pengekspor menurun. "Retreat" mungkin 


\section{EKOMBIS Sains}

merupakan posisi tidak menguntungkan tetapi dapat menjadi masukan bagi negara pengekspor untuk beralih dan mendukung komoditas lain yang memiliki daya saing lebih baik. Nurhayati et al. (2018) menambahkan bahwa indeks RCA dan EPD bisa digabungkan untuk menentukan klusterisasi pengembangan pasar ekspor. Metode penggabungan ini dinamakan metode X-Model Potential Export Products.

\section{METODE PENELITIAN}

\section{Jenis dan Sumber Data}

Penelitian menganalisa secara deskriptif daya saing dan potensi ekspor mobil Indonesia di Kawasan Asia Selatan dengan menggunakan 3 metode: RSCA, Export Product Dynamics (EPD), dan X-Model Potential Export Products.

Jenis data yang digunakan dalam penelitian ini adalah data sekunder yang diunduh dari UN Comtrade (2021). Data berupa data tahunan ekspor mobil Indonesia dengan kode HS 8703 ke negara-negara di kawasan Asia Selatan periode 2006 sampai 2019. Dari 8 negara di kawasan Asia Selatan, hanya 4 negara yang mengimpor mobil Indonesia secara kontinyu: Bangladesh, India, Pakistan, dan Sri Lanka.

Data tersebut dianalisis dengan 3 metode yaitu RSCA, EPD, dan X-Model Potential Export Products.

\section{Revealed Symmetric Comparative Advantage (RSCA)}

RCA dicetuskan pertama kali oleh Balassa pada tahun 1965. Indeks RCA dihitung dengan persamaan berikut:

$$
R C A_{t}=\left(\frac{x_{i t}}{X_{i t}}\right) /\left(\frac{m_{i t}}{M_{i t}}\right)
$$

dimana:

$R C A_{t}:$ indeks RCA di tahun $t$; $x_{i t}$ : nilai ekspor mobil Indonesia ke negara $i$ pada tahun $t$;

$X_{i t}$ : nilai total ekspor Indonesia ke negara $i$ pada tahun $t$

$m_{i t} \quad$ : nilai total impor mobil negara $i$ pada tahun $t$

$M_{i t} \quad$ : nilai total impor negara $i$ pada tahun $t$.

Jika $R C A_{t}>1$ maka ekspor mobil Indonesia mempunyai keunggulan komparatif di negara $i$ pada tahun $t$.

Oleh karena indeks RCA memiliki nilai asimetris, maka menurut Gandolfo (2014) RCA bisa diubah menjadi RSCA dengan rumus berikut:

$$
R S C A_{t}=\left(R C A_{t}-1\right) /\left(R C A_{t}+1\right)
$$

Jika $R S C A_{t}>0$ maka ekspor mobil Indonesia mempunyai keunggulan komparatif di negara $i$ pada tahun $t$.

Menurut Laursen (2015), indeks RSCA di atas bisa digunakan untuk melihat kestabilan dan tren daya saing dengan menggunakan persamaan regresi di bawah ini:

$$
R S C A_{t}=\alpha+\beta\left(R S C A_{t-1}\right)+\varepsilon_{t}
$$

dimana $\alpha$ dan $\beta$ adalah koefisien regresi Ordinary Least Square (OLS) dari persamaan di atas.

Daya saing dikatakan stabil jika nilai $\beta \approx 1$. Sedangkan $\beta / R$ menunjukkan tren daya saing dimana $R$ adalah koefisien korelasi. Jika $\beta / R>1$ maka daya saing memiliki trend positif.

\section{Export Product Dynamics (EPD)}

Berdasarkan Wardani \& Mulatsih (2017), posisi mobil Indonesia di sumbu X ditentukan oleh persamaan berikut:

$$
\frac{\left(\sum_{t=1}^{t}\left(\frac{x_{i t}}{m_{i t}}\right)_{t}-\sum_{t=1}^{t}\left(\frac{x_{i t}}{m_{i t}}\right)_{t-1}\right) \times 100 \%}{T}
$$




\section{EKOMBIS Sains}

Sedangkan posisi mobil Indonesia di sumbu

Y ditentukan oleh persamaan berikut:

$$
\frac{\left(\sum_{t=1}^{t}\left(\frac{X_{i t}}{M_{i t}}\right)_{t}-\sum_{t=1}^{t}\left(\frac{X_{i t}}{M_{i t}}\right)_{t-1}\right) \times 100 \%}{T}
$$

dimana $T$ adalah banyaknya tahun yang diteliti.

\section{X-Model Potential Export Products}

Berdasarkan Nurhayati et al. (2018), pengembangan pasar ekspor ditentukan oleh RSCA dan EPD sesuai Gambar 4 di bawah ini:

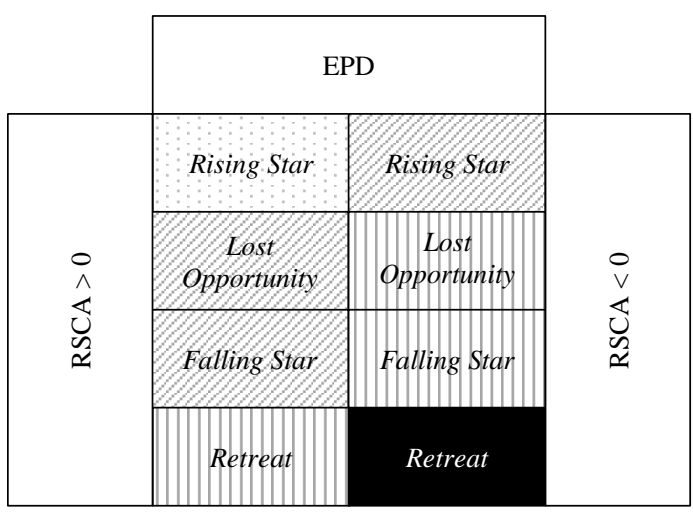

Gambar 4. Analisis X-Model Potential Export Products

Keterangan:

\begin{tabular}{|c|c|}
\hline $\begin{array}{l}\text { Pengembangan Pasar } \\
\text { Optimis }\end{array}$ & Pengembangar pasar \\
\hline $\begin{array}{c}\text { Pengembangan Pasar } \\
\text { Kurang Potensial }\end{array}$ & $\begin{array}{l}\text { Pengembangan Pasar } \\
\text { Tidak Potensial }\end{array}$ \\
\hline
\end{tabular}

\section{HASIL DAN PEMBAHASAN}

\section{Hasil Analisis RSCA}

Tabel 2. Indeks RSCA Ekspor Mobil Indonesia di Negara-negara Kawasan Asia Selatan

\begin{tabular}{ccccc}
\hline Tahun & Bangladesh & India & Pakistan & Sri Lanka \\
\hline 2006 & -0.8801 & -0.9892 & -0.1101 & -0.9621 \\
2007 & -0.6996 & -0.9982 & -0.7023 & -0.6957 \\
2008 & -0.6472 & -0.8340 & -0.4888 & -0.6465 \\
2009 & -0.7931 & -0.9337 & -0.5564 & -0.7621
\end{tabular}

\begin{tabular}{ccccc}
2010 & -0.6332 & -0.9995 & -0.1239 & -0.8277 \\
2011 & -0.5621 & -0.9981 & -0.5312 & -0.6082 \\
2012 & -0.4331 & -0.9945 & -0.7974 & -0.7826 \\
2013 & -0.7717 & -0.9857 & -0.7495 & -0.1085 \\
2014 & -0.7725 & -0.9785 & -0.0105 & -0.6425 \\
2015 & -0.7997 & -0.8623 & -0.3735 & -0.8211 \\
2016 & -0.8224 & -0.9756 & 0.0142 & -0.8029 \\
2017 & -0.8966 & -0.9960 & 0.2081 & -0.0763 \\
2018 & -0.6344 & -0.9708 & 0.3265 & -0.2810 \\
2019 & -0.4352 & -0.9281 & 0.3234 & -0.1947 \\
\hline Rata-rata & -0.6986 & -0.9603 & -0.2551 & -0.5866 \\
\hline
\end{tabular}

Sumber: Data diolah

Hasil perhitungan indeks RSCA memperlihatkan bahwa daya saing ekspor mobil Indonesia masih lemah di pasar ekspor kawasan Asia Selatan karena ratarata nilai indeks RSCA < 0 (Tabel 2). Hanya di negara Pakistan yang menunjukkan nilai RSCA positif mulai tahun 2016. Dari keempat negara, mobil Indonesia memiliki daya saing paling rendah di India karena memiliki indeks RSCA paling kecil.

Dari Tabel 3 terlihat bahwa daya saing ekspor mobil Indonesia di kawasan Asia Selatan tidak stabil dan ketidakstabilan paling besar adalah India. Tabel 3 juga menunjukkan bahwa ekspor mobil Indonesia memiliki tren naik hanya di negara Sri Lanka.

Tabel 3. Kestabilan dan Tren Daya Saing Ekspor Mobil Indonesia di Kawasan Asia Selatan

\begin{tabular}{lcc}
\hline \multicolumn{1}{c}{ Negara } & Kestabilan $(\beta)$ & Tren $\beta / R$ \\
\hline Bangladesh & 0.2566 & 0.9365 \\
India & 0.0010 & 0.9872 \\
Pakistan & 0.4953 & 0.9944 \\
Sri Lanka & 0.1813 & 1.0707 \\
\hline
\end{tabular}

Sumber: Data diolah

\section{Hasil Analisis EPD}

Matriks EPD pada Gambar 5 menggambarkan posisi ekspor mobil Indonesia di kawasan Asia Selatan. Dari empat negara yang diteliti, mobil Indonesia mempunyai posisi Rising Star di 3 negara. Hal ini mengindikasikan bahwa ekspor mobil Indonesia masih mempunyai peluang untuk tumbuh di ketiga negara tersebut. 


\section{EKOMBIS Sains}

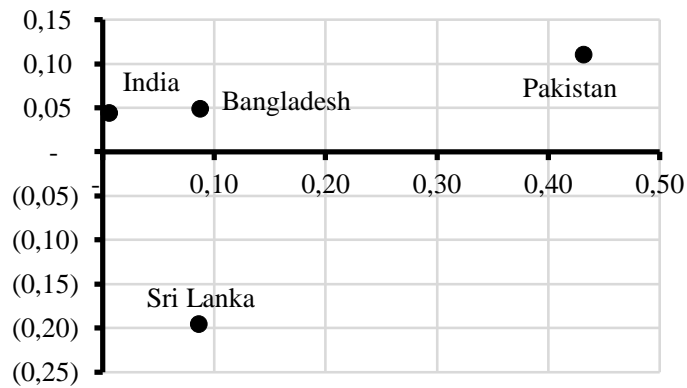

Gambar 5. Matriks EPD Ekspor Mobil Indonesia di kawasan Asia Selatan

Meskipun daya saing mobil Indonesia memiliki tren naik di Sri Lanka, ekspor Indonesia secara keseluruhan cenderung menurun. Akibatnya, ekspor mobil Indonesia ke Sri Lanka berada pada posisi Falling Star (Gambar 5).

\section{Hasil Analisis X-Model Potential Export Products}

Pada Tabel 4 terlihat bahwa Bangladesh, India, dan Pakistan merupakan pasar potensial bagi ekspor mobil Indonesia. Sedangkan Sri Lanka kurang potensial untuk dijadikan mitra dagang ekspor mobil Indonesia.

Tabel 4. Hasil Analisis $X$-Model Ekspor Mobil Indonesia di Kawasan Asia Selatan

\begin{tabular}{lclc}
\hline \multicolumn{1}{c}{ Negara } & Rata-rata RSCA & EPD & X-Model \\
\hline Bangladesh & -0.6986 & Rising Star & Pasar Potensial \\
India & -0.9603 & Rising Star & Pasar Potensial \\
Pakistan & -0.2551 & Rising Star & Pasar Potensial \\
Sri Lanka & -0.5866 & Falling Star & Pasar Kurang Potensial \\
\hline
\end{tabular}

\section{Pembahasan}

Berdasarkan hasil analisis RSCA, mobil Indonesia memiliki daya saing paling lemah di India. Lemahnya daya saing ini karena India juga sebagai produsen mobil (Roy, 2017), sehingga ekspor mobil Indonesia menghadapi kompetisi yang sengit dengan produsen mobil lokal.

Selain itu, indeks RSCA menunjukkan bahwa daya saing ekspor mobil Indonesia di kawasan Asia Selatan juga masih lemah dikarenakan India juga mengekspor produksi mobilnya (UN Comtrade, 2021). Negara-negara di kawasan Asia Selatan lebih cenderung mengimpor dari India karena lebih dekat. Uniknya, justru Pakistan lebih cenderung untuk mengimpor dari negara selain India akibat hubungan politik yang buruk dengan India.

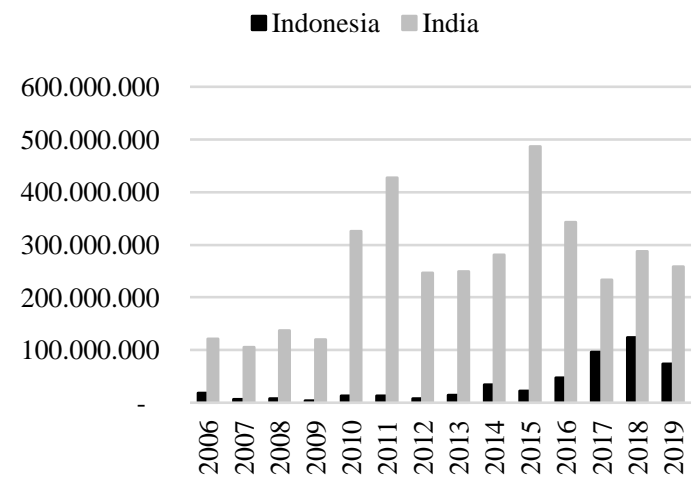

Gambar 6. Ekspor Mobil Indonesia dan India di Kawasan Asia Selatan (UN Comtrade, 2021)

Oleh karena itu, untuk meningkatkan pangsa pasar, Indonesia membutuhkan strategi khusus seperti mengekspor varian mobil yang tidak diproduksi oleh India dan diminati oleh penduduk di kawasan tersebut contohnya Sport Utility Vehicle (SUV) dan sedan. Namun, produksi SUV dan sedan masih tergolong sedikit dibandingkan dengan Multi-Purpose Vehicle (MPV). Hal ini dikarenakan biaya produksi SUV dan sedan masih lebih mahal dari MPV.

Salah satu faktor yang menyebabkan biaya produksi SUV dan sedan lebih mahal 
adalah tingginya minat masyarakat Indonesia pada varian MPV. Sehingga MPV bisa diproduksi lebih masif dibandingkan varian lainnya yang mengakibatkan biaya produksi rata-rata relatif lebih rendah dan harga lebih murah (Gaikindo, 2020).

Faktor pajak juga mempengaruhi penjualan sedan di pasar domestik dimana mobil sedan dikenakan PPnBM (Pajak Pertambahan Nilai Barang Mewah) di pasar domestik. Akibatnya masyarakat Indonesia kurang berminat untuk membeli varian tersebut. Oleh sebab itu, produsen mobil pun enggan menambah kapasitas produksi sedan. Hal ini dikarenakan pasar domestik Indonesia masih menjadi pilar utama industri mobil, sedangkan ekspor belum menjadi target utama (Gaikindo, 2018, 2019).

Selain faktor jarak, faktor lainnya yang menyebabkan harga mobil Indonesia bisa lebih mahal dari India adalah upah minimum di India lebih murah dari Indonesia. Upah minimum di India antara US\$ 214.38 US\$ 235.76 per bulan, sedangkan upah minimum di sentra industri mobil, Karawang, mencapai Rp. 4,798,312 atau US\$ 330.92 per bulan. Oleh karena itu, Indonesia akan kalah bersaing dengan India dari sisi harga kalau seandainya Indonesia mengekspor mobil dengan varian sejenis yang diproduksi di India.

\section{KESIMPULAN}

Meskipun daya saing ekspor mobil Indonesia masih menunjukkan performa yang rendah, mobil Indonesia memiliki potensi untuk diekspor di kawasan Asia Selatan.

Rendahnya daya saing ini ditunjukkan dengan rata-rata indeks RSCA yang bernilai negatif di keempat negara yang diteliti. Kecuali Pakistan dimana sejak tahun 2016 menunjukkan indeks RSCA yang positif sebagai dampak hubungan diplomatis yang kurang harmonis Pakistan-India.

Berdasarkan matriks EPD, mobil Indonesia berada di posisi Rising Star di tiga negara kecuali Sri Lanka yang berada pada posisi Falling Star. Hal ini mengindikasikan bahwa ekspor mobil Indonesia masih memiliki peluang untuk tumbuh di kawasan Asia Selatan meskipun daya saing masih lemah.

Hasil analisis $X$-Model menunjukkan bahwa Bangladesh, India, dan Pakistan merupakan pasar potensial untuk mobil Indonesia, hanya Sri Lanka yang kurang potensial untuk dijadikan tujuan ekspor.

Penelitian ini hanya menggunakan nilai ekspor dalam perhitungan data secara general dan tidak menggunakan data berdasarkan ekspor per unit atau mengelompokkan berdasarkan varian mobil mengingat masing-masing negara memiliki preferensi jenis mobil yang berbeda.

Dari hasil ketiga metode tersebut perlu dilakukan penelitian lebih lanjut untuk mengetahui faktor-faktor apa yang mempengaruhi ekspor mobil Indonesia di kawasan Asia Selatan dan bagaimana cara mengatasi faktor-faktor yang mempunyai pengaruh negatif dan mengoptimalkan faktor-faktor yang mempunyai pengaruh positif.

\section{DAFTAR PUSTAKA}

Abedini, J., \& Péridy, N. (2009). The Emergence of Iran in the World Car Industry: An Estimation of its Export Potential. World Economy, 32(5), 790818. https://doi.org/10.1111/j.14679701.2008.01153.x

Alexander, I., \& Nadapdap, H. J. (2019). Analisis Daya Saing Ekspor Biji Kopi Indonesia Di Pasar Global Tahun 2002-2017. Jurnal Sosial Ekonomi Pertanian, 12(2), 1. https://doi.org/10.19184/jsep.v12i2.11 271

Ashari, U., Sahara, S., \& Hartoyo, S. (2016). Daya Saing Udang Segar Dan Udang Beku Indonesia Di Negara Tujuan Ekspor Utama. Jurnal 
Manajemen Dan Agribisnis, 13(1), 113. https://doi.org/10.17358/jma.13.1.1

Asrol, A., \& Heriyanto, H. (2017). Daya Saing Ekspor Pala Indonesia di Pasar Internasional. Jurnal Dinamika Pertanian, 33(2), 179-188. https://doi.org/10.25299/dp.2017.vol3 3(2).3831

Balassa, B. (1965). Trade Liberalisation and "Revealed" Comparative Advantage. The Manchester School of Economic and Social Studies, 32, 99123.

Bano, S., \& Scrimgeour, F. (2012). The Export Growth and Revealed Comparative Advantage of the New Zealand Kiwifruit Industry.

International Business Research, 5(2), 73-82.

https://doi.org/10.5539/ibr.v5n2p73

BPS-Statistics Indonesia. (2021). Jumlah Tenaga Kerja Industri Besar Dan Sedang Menurut Sub Sektor, 20082017. Industri Besar Dan Sedang. https://www.bps.go.id/statictable/2011 /02/14/1063/jumlah-tenaga-kerjaindustri-besar-dan-sedang-menurutsubsektor-2000-2017.html

Departemen Kebijakan Ekonomi dan Moneter. (2018). Kajian Ekonomi dan Keuangan Regional. In Laporan Nusantara (Vol. 13, Issue 4). https://www.bi.go.id/id/publikasi/lapor an/Documents/Laporan Nusantara November 2018.pdf

Direktorat Perencanaan Makro dan Analisis Statistik. (2020). Perkembangan Ekonomi Indonesia dan Dunia Triwulan II 2020. In Kementerian PPN/Bappenas (Vol. 4, Issue 2). https://www.bappenas.go.id/files/3716 /0118/7564/Laporan_Perkembangan_ Ekonomi_Indonesia_dan_Dunia_Triw ulan_II_2020.pdf
Ermawati, T., \& Saptia, Y. (2013). Kinerja Ekspor Minyak Kelapa Sawit Indonesia. Buletin Ilmiah Litbang Perdagangan, 7(2), 129-148.

Esterhuizen, D. (2006). Measuring and Analyzing Competitiveness in the Agribusiness Sector: Methodological and Analytical Framework. University of Pretoria, 107(4), 823-824. https://doi.org/10.1086/689555

Gaikindo. (2018). GAIKINDO Ikut Suarakan Harmonisasi Pajak Otomotif. Artikel Economy \& Industry. https://www.gaikindo.or.id/gaikindoikut-suarakan-harmonisasi-pajakotomotif/

Gaikindo. (2019). Pemerintah Janjikan Pajak Sedan Turun. Artikel Economy $\&$ Industry. https://www.gaikindo.or.id/pemerintah -janjikan-pajak-sedan-turun/

Gaikindo. (2020, June). GAIKINDO: Indonesia Perlu Tingkatkan Produksi Mobil SUV demi Ekspor. Artikel Economy \& Industry; Gaikindo. https://www.gaikindo.or.id/gaikindoindonesia-perlu-tingkatkan-produksimobil-suv-demi-ekspor/

Gaikindo. (2021a). Indonesian Automobile Industry Data. Data.

https://www.gaikindo.or.id/en/indonesi an-automobile-industry-data/

Gaikindo. (2021b). Kementerian Perindustrian - Otomotif Bakal Perluas Ekspor dari Indonesia Gaikindo. https://www.gaikindo.or.id/kementeria n-perindustrian-otomotif-bakalperluas-ekspor-dari-indonesia/

Gandolfo, G. (2014). International Trade 
Theory and Policy (2nd ed.). SpringerVerlag. https://doi.org/10.1007/978-3642-37314-5

Hagi, Hadi, S., \& Tety, E. (2012). Analisis Daya Saing Ekspor Minyak Sawit Indonesia dan Malaysia di Pasar Internasional. Repository Universitas Riau.

Hasibuan, A. M., Nurmalina, R., \& Wahyudi, A. (2012). Analisis Kinerja dan Daya Saing Perdagangan Biji Kakao dan Produk Kakao Olahan Indonesia di Pasar Internasional. Buletin Riset Tanaman Rempah Dan Aneka Tanaman Industri, 3(1), 57-70. https://doi.org/10.21082/jtidp.v3n1.20 12.p57-70

Herciu, M. (2013). Measuring International Competitiveness of Romania by Using Porter's Diamond and Revealed Comparative Advantage. Procedia Economics and Finance, 6(2013), 273-279.

https://doi.org/10.1016/S22125671(13)00140-8

Kaunang, W. R. (2013). Daya Saing Ekspor Komoditi Minyak Kelapa Sulawesi Utara. Jurnal Riset Ekonomi, Manajemen, Bisnis Dan Akuntansi, 1(4), 1304-1316.

Krugman, P. R., Obstfeld, M., \& Melitz, M.

J. (2018). International Economics:

Theory \& Policy (A. Srivastava \& P. Banerjee (eds.); 11th ed.).

Kusuma, R. L., \& Firdaus, M. (2015). Daya Saing dan Faktor yang Memengaruhi Volume Ekspor Sayuran Indonesia Terhadap Negara Tujuan Utama. Jurnal Manajemen Dan Agribisnis, 12(3), 226-236. https://doi.org/10.17358/jma.12.3.226

La Ola, L. O. (2014). Efisiensi Biaya
Produksi dan Daya Saing Komoditi Perikanan Laut di Pasar Lokal dan Pasar Ekspor. Jurnal Bisnis Perikanan, 1(1), 39-50.

Laursen, K. (2015). Revealed Comparative Advantage and the Alternatives as Measures of International Specialization. Eurasian Business Review, 5(1), 99-115. https://doi.org/10.1007/s40821-0150017-1

Mashari, S., Nurmalina, R., \& Suharno. (2019). Dinamika Daya Saing Ekspor Udang Beku dan Olahan Indonesia di Pasar Internasional. Jurnal Agribisnis Indonesia, 7(1), 37-52.

Mushanyuri, B. E., \& Mzumara, M. M. (2013). An Assessment of Comparative Advantage of Mauritius. European Journal of Sustainable Development, 2(3), 35-42. https://doi.org/10.14207/ejsd.2013.v2n 3 p35

Nauly, D., Daris, E., \& Nuhung, I. A. (2014). Daya Saing Ekspor Kakao Olahan Indonesia. Agribusiness Journal, 8(1), 15-28. https://doi.org/10.15408/aj.v8i1.5126

Nihayah, D. M. (2012). Kinerja Daya Saing Komoditas Sektor Agroindustri Indonesia. Jurnal Bisnis Dan Ekonomi, 19(1), 37-48.

Nurhayati, E., Hartoyo, S., \& Mulatsih, S. (2018). Analisis Pengembangan Ekspor Cengkeh Indonesia. Jurnal Ekonomi Dan Kebijakan Pembangunan, 7(1), 21-42.

OECD. (2012). OECD Reviews of Regulatory Reform: Indonesia Market Openess (Issue September 2012). OECD. http://www.oecdilibrary.org/content/book/9789264042 940-en\% $5 \mathrm{Cn}$ 
OICA. (2021). Sales Statistics. http://www.oica.net/category/salesstatistics/

Patone, C. D., Kumaat, R. J., \& Mendeij, D. (2020). Analisis Daya Saing Ekspor Sawit Indonesia Ke Negara Tujuan Ekspor Tiongkok Dan India. Jurnal Berkala Ilmiah Efisiensi, 20(03), 2232.

Pradipta, A. (2014). Posisi Daya Saing dan Faktor-Faktor Yang Memengaruhi Ekspor Buah-Buahan Indonesia. Jurnal Manajemen \& Agribisnis, 11(2), 129-143. https://doi.org/10.17358/jma.11.2.129143

Purnamasari, M., Hanani, N., \& Huang, W.-C. (2014). Analisis Daya Saing Ekspor Kopi Indonesia di Pasar Dunia. Agricultural Socio-Economic Journal, 14(1), 58-66. https://agrise.ub.ac.id/index.php/agrise /article/view/117/143

Rossato, F. G. F. S., Susaeta, A., Adams, D. C., Hidalgo, I. G., Araujo, T. D. De, \& Queiroz, A. De. (2018). Comparison of Revealed Comparative Advantage Indexes with Application to Trade Tendencies of Cellulose Production from Planted Forests in Brazil, Canada, China, Sweden, Finland and the United States. Forest Policy and Economics, 97(September), 59-66. https://doi.org/10.1016/j.forpol.2018.0 9.007

Roy, T. (2017). The Economy of South Asia: From 1950 to the Present (K. Deng (ed.)). Palgrave Studies in Economic History. https://doi.org/10.1007/978-3-31954720-6

Salvatore, D. (2013). International
Economics (J. Hollenbeck \& J. Manias (eds.); 11th ed.). John Wiley \& Sons, Inc.

Sari, A. R., Hakim, D. B., \& Anggraeni, L. (2014). Analisis Pengaruh Non-Tariff Measures Ekspor Komoditi Crude Palm Oil (CPO) Indonesia Ke Negara Tujuan Ekspor Utama. Jurnal Ekonomi Dan Kebijakan Pembangunan, 3(2), 111-135. https://doi.org/10.29244/jekp.3.2.111135

Sarwono, \& Pratama, W. (2014). Analisis Daya Saing Kedelai Indonesia. Jurnal Ekonomi Dan Kebijakan, 7(2), 134140. https://doi.org/10.15294/jejak.v7i2.389 4

Satryana, M. H., \& Karmini, N. L. (2016). Analisis Daya Saing Ekspor Teh Indonesia ke Pasar ASEAN Periode 2004-2013. E-Jurnal Ekonomi Pembangunan Universitas Udayana, 5(5), 598-613.

Startienè, G., \& Remeikienè, R. (2014). Evaluation of Revealed Comparative Advantage of Lithuanian Industry in Global Markets. Procedia - Social and Behavioral Sciences, 110(2014), 428438.

https://doi.org/10.1016/j.sbspro.2013.1 2.887

Suntharalingam, C., Ahmad, T. M. A. T., Ali, A. K., Rusli, R., \& Halim, N. A. (2011). Competitiveness of Malaysia's Fruits in the Global Agricultural and Selected Export Markets: Analyses of Revealed Comparative Advantage (RCA) and Comparative Export Performance (CE). Economic and Technology Management Review, 6, 1-17.

Syahputra, Y. R., Tarumun, S., \& Yusri, J. 
(2014). Analisis Daya Saing Ekspor Karet Alam (Natural Rubber) Indonesia di Pasar Internasional. Jurnal Online Mahasiswa Fakultas Pertanian Universitas Riau, 1(2), 1-9.

The Ministry of Industry Republic of Indonesia. (2018). Making Indonesia 4.0. The Ministry of Industry Republic of Indonesia.

https://www.kemenperin.go.id

The Ministry of Trade Republic of Indonesia. (2021). Perkembangan Ekspor Non Migas (Komoditi). Portal Statistik Perdagangan. http://statistik.kemendag.go.id/growthof-non-oil-and-gas-export-commodity

Tumengkol, W. L., Palar, S. W., \& Rotinsulu, D. C. (2015). Kinerja dan Daya Saing Ekspor Hasil Perikanan Laut Kota Bitung. Jurnal Berkala Ilmiah Efisiensi, 15(1), 1-16.

Tupamahu, Y. M. (2015). Analisis Daya Saing Ekspor Cengkeh Indonesia di Kawasan ASEAN dan Dunia. Jurnal
Agribisnis Perikanan, 8(1), 27. https://doi.org/10.29239/j.agrikan.8.1. 27-35

UN Comtrade. (2021). UN Comtrade: International Trade Statistics. https://comtrade.un.org/data

Wardani, M. A., \& Mulatsih, S. (2017). Analisis Daya Saing dan Faktor-Faktor yang Memengaruhi Ekspor Ban Indonesia ke Kawasan Amerika Latin. Jurnal Ekonomi Dan Kebijakan Pembangunan, 6(1), 81-100. https://doi.org/10.29244/jekp.6.1.81100

World Bank. (2021). The World Bank Data. https://data.worldbank.org/indicator

Zuhdi, F., \& Suharno. (2015). Analisis Daya Saing Ekspor Kopi Indonesia dan Vietnam di Pasar ASEAN 5. Jurnal Habitat, 26(3), 152-162. https://doi.org/10.22437/jiseb.v20i1.50 28 